https://doi.org/10.30910/turkjans.633562

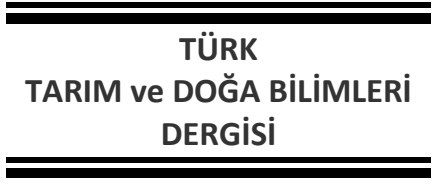

\section{Araştırma Makalesi}

\title{
Ege Bölgesinde Zeytin İşletmelerinin Maliyetleri ve Sorunları ${ }^{\mathrm{a}}$
}

\author{
Faruk ADIGÜZEL ${ }^{1 *}$, Nuray KIZILASLAN² \\ ${ }^{1}$ Küçükçekmece İlçe Tarım ve Orman Müdürlüğü, 34295 İstanbul, Türkiye \\ ${ }^{2}$ GOP Üniversitesi, Ziraat Fakültesi, Tarım Ekonomisi Bölümü, 60240, Tokat, Türkiye \\ *Sorumlu yazar: farukadiguzel13@hotmail.com
}

\begin{abstract}
Geliş Tarihi: 21.01.2019
Düzeltme Geliş Tarihi: 26.07.2019

Kabul Tarihi: 22.08.2019

Özet

$\mathrm{Bu}$ araştırmada Ege Bölgesinde zeytin yetiştiren tarım işletmelerinin mevcut yapısı, ürün maliyetleri ve sorunları ortaya konulmuştur. Araştırma alanı Ege Bölgesinde zeytin yetiştiriciliğinin yoğun olarak yapıldığı Aydın, İzmir, Manisa ve Muğla illeri olup, araştırma verileri tabakalı tesadüfi örnekleme yöntemi ile seçilen 152 adet işletmeden anket yöntemi ile elde edilmiştir. İşletmelerde işletme başına nüfusun gruplar itibariyle 3.19 ile 4.24 kişi arasında değiştiği belirlenirken bu değer işletmeler ortalamasında 3.66 kişi olarak hesaplanmıştır. İşletmeler ortalamasında okur-yazarlık oranı \%95.88 ve ortalama öğrenim süresi 6.13 yıl olarak bulunmuştur. İşletme yöneticilerinin yaşı ortalamada 54.40 yıl ve öğrenim süresi 5.82 yıl olarak saptanmıştır. İşletmeler ortalamasında toplam kullanılan işgücü 442.54 EiG olarak bulunurken bunun $\% 73.28$ 'ini aile işgücünün oluşturduğu belirlenmiştir. İşletmeler ortalamasında toplam işletme arazisi 91.24 da'dır ve bu arazinin \%64.54'ü zeytin arazisidir. Ham zeytin ürününün toplam üretim masrafları içerisinde değişken masrafların \%47.17 ve sabit masrafların \%52.83 oranında pay aldığı tespit edilmiştir. Değişken masraf unsurlarından hasat (\%16.90) ve bakım (\%13.06) masrafları ön plana çıkarken sabit masraflardan arazi kirası (\%37.70) en önemli masraf kalemidir. İşletmelerde arazi büyüklükleri arttıkça ham zeytin, sofralık zeytin ve zeytinyağı maliyetlerinin azalış gösterdiği belirlenmiştir. Zeytincilik sektörünün geliştirilmesi için öncelikle işletme düzeyinde mevcut durum ve sorunların bilinmesi, beklentilerin önemsenmesi sağlanmalıdır.
\end{abstract}

Anahtar kelimeler: Zeytin işletmeleri, nüfus, arazi, sermaye, maliyetler ve sorunlar, Ege Bölgesi.

\section{Costs and Problems of Olive Farms in Aegean Region}

\begin{abstract}
In this study, it was determined current structure, costs and problems of farms producing olive in Aegean Region. The research area was Aydın, İzmir, Manisa and Muğla provinces in Aegean Region where olive cultivation is produced intensively. The data were obtained from 152 farms via questionnaire with stratified random sampling method. The population per farm was determined between 3.19 and 4.24 people in groups and this value was calculated as 3.66 people in the average of farms. Literacy rate was $95.88 \%$ and education period was 6.13 years on average. The average age and education period of managers was 54.40 and 5.82 years, respectively. Total labour used per farms average was 442.54 man-days and $73.28 \%$ of this was family labour. The land per the farms average was 91.24 decare, of which $64.54 \%$ was olive lands. Variable expenses and fixed costs were determined as $47.17 \%$ and $52.83 \%$, respectively in total production costs for crude olives. The most important variable costs were harvest (16.92\%) and maintenance costs (13.06\%). Land rent has the largest share (37.70\%) in fixed costs. As the size of land in farms was increased, it was determined decreased of crude olives, processed olives and olive oil costs. In order to develop the olive sector, primarily in the farm level the current status and problems should be known and the expectations should be taken into consideration.
\end{abstract}

Key words: Olive farms, population, land, capital, costs and problems, Aegean Region. 


\section{Giriş}

Insanların zorunlu ve temel ihtiyaçlarını karşılama özelliği ile gelişmiş, az gelişmiş ve gelişmekte olan bütün ülkelerin ekonomilerinde özel bir yeri ve önemi olan tarım sektörüne ve dolayısı ile ülke ekonomisine üretim yoluyla katkı sağlayan önemli tarımsal ürünlerden birisi de zeytindir (Yapıcı, 2006). Zeytin bir Akdeniz bitkisidir ve yetişmesine uygun iklimsel koşullara sahip yerlerde toprak kalitesi açısından fazla seçicilik göstermeksizin yetiştirilebilmektedir. Bu durum mevcut alanları iyi bir şekilde değerlendirme olanağı sağlamaktadır. Toprağın diğer ürünler için uygun olmadığı yerlerde, toprak değerini arttırmakla kalmayıp, aynı zamanda toprağın korunmasına da (erozyon yoluyla kaybolması) yardımcı olduğu için zeytincilik yapılan ülkelerin ekonomisinde önemli bir rol oynamakta, ulusal otoriteleri ve uluslararası kuruluşları sürekli ilgilendiren, çevre sorunları ile savaşta ve çevre korunmasında yardımcı olan bir ürün durumundadır. Hasat edildiği şekilde kullanılma olanağı olmayan zeytin, yağa ya da salamuraya işlenerek tüketilmektedir. Yağa işleme sırasında yan ürün olarak elde edilen pirinadan da kimya sanayinde ya da yakacak olarak yararlanılması olanaklıdır (Karslı, 2006). Zeytin ve zeytinyağı üretimi sağlıklı beslenmede, öz kaynakların değerlendirilmesinde, istihdam oluşturmada, diğer sanayi kollarına ve kendi alt gruplarına hammadde temin etmede ve yüksek katma değer sağlaması nedeniyle tarım sektörü ve dolayısıyla ülke ekonomisi için büyük öneme sahiptir (Anaç, 2005).

Türkiye'de zeytin üretimine ait veriler incelendiğinde üretim alanının yıllar itibarı ile artış göstermesine karşın üretim miktarı ve dekara verim düzeyi periyodisiteye bağı olarak dalgalı bir seyir göstermektedir. Türkiye'nin zeytin üretim alanının 2016 yılında 8455420 da ve üretim miktarının 1730 000 ton olduğu rapor edilirken Dünya zeytin üretim alanından $\% 7.94$ ve üretim miktarından $\% 8.98$ oranında pay almaktadır. Türkiye'de dekara zeytin verimi ise 2016 yılında gerçekleşen 204.60 kg/da verim ortalaması ile $180.91 \mathrm{~kg} / \mathrm{da}$ olan Dünya ortalamasının üzerindedir (Anonymous, 2018). Türkiye'de 2016 yılı itibariyle toplam tarım alanlarının \%3.56'sını zeytinlikler oluştururken Ege Bölgesi tarım alanlarının \%16.45'inde zeytin üretimi yapılmaktadır. Türkiye toplam zeytin üretim alanının sofralık zeytinde \%47.62'si ve yağlık zeytinde \%56.16'sı Ege Bölgesinde bulunmaktadır. Üretim alanına paralel olarak zeytin üretim miktarında da Ege Bölgesi ilk sırada olup, Türkiye sofralık zeytin üretiminin \%46.97'si ve yağlık zeytin üretiminin \%51.74'ü bu bölgede gerçekleştirilmiştir. Ayrıca, aynı yıl Türkiye toplam sofralık zeytin ağacı sayısının \%46.01'i ve yağlık zeytin ağacı sayısının \%51.07'si Ege Bölgesinde bulunmaktadır (Anonim, 2018).

Sağlıklı beslenme bilincinin daha da önemsendiği günümüzde önemli bir ürün olarak görülen zeytinin iklim özellikleri itibariyle Türkiye'de yetiştirilmeye uygun önemli bir iç tüketim ve ihraç ürünü olması, bölge halkının önemli geçim kaynaklarından biri olması, zeytin üreten işletmelerin sosyo-ekonomik yapısının ortaya konulması, araştırma alanındaki üretimin Türkiye toplam üretim alanı ve miktarı içerisinde ilk sırada olması, işletme düzeyinde bölgesel bir çalışma olması çalışmayı gerekli kılan nedenlerdir. Bu bağlamda araştırmada Ege Bölgesinde zeytin yetiştiriciliği yapan tarım işletmelerinin mevcut yapısı, ürün maliyetleri ve sorunlarının ortaya konulması amaçlanmıştır.

\section{Materyal Ve Yöntem}

Araştırmanın materyalini Ege Bölgesinde Aydın, İzmir, Manisa ve Muğla illerinde zeytin yetiştiriciliği yapan tarım işletmelerinden anket yöntemi ile elde edilen birincil veriler ile daha önce farklı yörelerde yapılmış benzer bilimsel çalışmalardan sağlanan ikincil veriler oluşturmuştur. Materyalin toplanması aşamasında bölgede zeytin üretimi yapan tarım işletmelerinin sayıları ve arazi varlıklarına ilişkin bilgiler güncel adıyla Tarım ve Orman Bakanlığı'nın Çiftçi Kayıt Sistemi'nden (ÇKS) elde edilmiştir. Bakanlık çalışanlarının görüşleri doğrultusunda doğal ve coğrafi özellikler ile üretim ve pazarlama açısından bölgeyi temsil edebilecek 15 ilçe gayeli örnekleme yöntemi ile seçilmiştir (Çiçek ve Erkan, 1996). Ana kitlenin \%2.70'ini oluşturan 1 dekardan küçük ve 500 dekardan büyük arazi varlığına sahip uç işletmeler örnekleme çerçevesinden çıkartılmıştır. Popülasyona ilişkin Varyasyon Katsayısının \%138.52 olarak hesaplanması nedeniyle örnek hacminin tespitinde Tabakalı Örnekleme Yöntemlerinden Neyman Yöntemi kullanılmıştır (Çiçek ve Erkan, 1996). Örnek hacminin belirlenmesinde $\% 99$ güven sınırında ( $\mathrm{t}=2.58$ ) ve ortalamadan \%10 sapma tercih edilmiştir. Yapılan hesaplama sonucunda örnek hacmi 152 işletme olarak belirlenmiş ve işletmeler 1-15 da, 16-50 da ve 51-+ da olmak üzere 3 tabakaya ayrılmıştır. Tabaka sayısı ve sınırlarının belirlenmesinde çok sayıda seçenek denenmiş ve tabakalara ilişkin standart sapma ve varyasyon katsayısı bakımından en uygun olan seçenek tercih edilmiştir.

Araştırmada veri toplama yöntemlerinden anket yöntemi kullanılmış olup, işletmelerde muhasebe kayıtlarının bulunmayacağı, üretim ve pazarlama faaliyetleri ile ilgili kayıt tutulmayacağı varsayımından hareketle birincil materyalin toplanması aşamasında Direkt Mülakat Yöntemi 
tercih edilmiştir. Anket uygulaması Ağustos-Ekim 2015 döneminde önceden haber verilmeksizin üretici mahallinde çiftçilerle yüz yüze görüşülerek bizzat araştırmacılar tarafından yapılmıştır.

$$
\text { Araştırmanın analizi aşamasında, }
$$
işletmelerin sosyo-ekonomik özellikleri olarak öncelikle nüfus, öğrenim durumu, işgücü, arazi varlığı özellikleri, sermaye yapısı ve ham zeytin, sofralık zeytin ve zeytinyağı maliyetleri ortaya konulmuş ve zeytin yetiştiricilerinin üretimde karşılaştıkları sorunlar ve devletten beklentileri açıklanmıştır.

İşletmelerde nüfus yapısı; cinsiyet, yaş ve öğrenim durumlarına göre incelenmiştir. Nüfusun öğrenim düzeyi yıl esası üzerinden ele alınmıştır. İşletmelerin işgücü potansiyeli belirlenirken hem kişi hem de Erkek İşgücü Birimi (ElB) olarak değerlendirilmiştir (Aras 1988). İşletme yöneticilerinin kişisel nitelikleri veya sosyal özellikleri, işletmelerin yönetim biçimi, organizasyonu, teknolojik yenilikleri benimsenmesi ve uygulanması bakımından önemli olduğu ifade edilmektedir (Esengün, 1990). Bu nedenle çalışmada işletme yöneticilerinin yaş ve öğrenim durumları da incelenmiştir. İşletmelerde arazi miktarı; işletmecinin mülk arazisine, ortağa ve kiraya tuttuğu arazi genişliklerinin eklenmesiyle hesaplanan değerden, ortağa ve kiraya verdiği arazi genişliklerinin çıkarılması yoluyla bulunmuştur (Erkuş ve ark., 1995). İşletmelerde arazi özellikleri olarak; arazi büyüklükleri, mülkiyeti ve tasarruf şekilleri, nev'ileri, parsel sayı ve büyüklükleri incelenmiştir.

İşletmelerin sermaye yapılarının analizinde sermaye miktar ve birimlerinin ortaya konulmasında sermayenin fonksiyonlarına göre sınıflandırılması esas alınmıştır (Aras, 1988; Erkuş ve ark., 1995; Karacan, 1991).

Araştırma bölgesinde zeytin yetiştiriciliği yapan tarım işletmelerinde ham zeytin, işlenmiş zeytin (sofralık) ve zeytinyağı için üretim masrafı ve unsurları hesaplanmış olup, bu sayede arazi genişlik grupları bakımından üretim maliyetlerindeki farklılıklar ortaya konulabilmiştir. Zeytincilik faaliyetinde üretim miktarını etkileyen en önemli faktörlerin başında periyodisite gelmektedir. Zeytin üretiminde periyodisitenin etkisini ortadan kaldırmak amacıyla masrafların hesaplanmasında zeytin üretim miktarı için var ve yok yılı ortalaması esas alınmıştır. Masraf unsurlarının hesaplanmasında işletme tarafından karşılanma durumuna bakılmaksızın alternatif maliyeti üzerinden hesaplama yapılmıştır. Tüm işletmelerde ham zeytin maliyetlerinin hesaplanmasına karşın, sofralık zeytin ve zeytinyağı için yapılan maliyet hesaplamalarında işletmede baskın olan ürün için analizler gerçekleştirilmiştir. İşletmelerde öncelikle ham zeytin ürününe ilişkin masraflar değişken ve sabit masraflar olarak ayrılmıştır. Değişken masraflar bakım (arazi işleme, budama, çapalama ve ot temizliği), gübreleme, ilaçlama, sulama, hasat, pazarlama ve işçilik masraflarından oluşmaktadır. Sabit masraflar ise daimi işçi, arazi kirası, genel yönetim giderleri, amortismanlar ve diğer (vergi, sigorta, harç vs.) masraflardır. Sofralık zeytin maliyetinde materyal, işçilik ve diğer (elektrik, su, kimyasal vs.) masraflar dikkate alınırken zeytinyağı maliyetlerinde ise fabrika payı ürün yüzdesi veya ürün ağırlık bedeli, taşıma ve depolama masrafları olarak hesaplanmıştır.

Üreticilerin fiilen kullandıkları materyaller için cari dönemde üretici tarafından ödenen bedeller esas alınmıştır (Güneş ve ark., 1988; Özçelik ve ark., 1998). Geçici işçi ücretleri için işletme yöneticisi tarafından belirtilen yörede geçerli işgücü bedelleri kullanılmıştır. Kira ile tutulan araziler için fiilen ödenen kira bedelleri ve mülk arazide ise alternatif kira bedelleri hesaba katılmıştır (Açıl, 1976). Genel idare giderleri, toplam değişken masrafların \%3'ü alınarak hesaplanmıştır. Bina amortismanı olarak değerinin $\% 2$ 'si ve alet-makine amortismanı için değerinin \%10'u hesaplanmıştır (Erkuş ve ark., 1995; İnan, 2001). Diğer giderlerin hesaplanmasında fiilen ödenen bedeller esas alınmıştır. Döner sermaye faizinin belirlenmesinde değişken masraflara T.C. Ziraat Bankasının bitkisel üretim kredilerine uyguladığı faiz oranının yarısı uygulanmıştır (Erkuş ve Demirci, 1996).

\section{Bulgular ve Tartışma \\ Zeytin işletmelerinde nüfus, öğrenim durumu ve işgücü yapısı}

Zeytin işletmelerinde nüfus yapısı miktar olarak incelendiğinde işletme başına düşen nüfus miktarı işletmeler ortalamasında 3.66 kişi bulunmuştur. İşletmelerin zeytin arazisi genişledikçe işletme başına düşen nüfus miktarının arttığı belirlenmiştir. Benzer çalışmalarda nüfus miktarı Tunalıoğlu ve Gökçe (2002)'ye göre 4.20 kişi, Anaç (2005)'a göre 3.16 kişi, Özgürsoy (2006)'a göre 5.50 kişi, Yapıcı (2006)'ya göre 3.49 kişi, Gençler (2009)'e göre 3.45 kişi, Çukur ve ark. (2013)'na göre 3.17 kişi, Apaydın ve ark., (2014)'na göre 4.80 kişi olarak hesaplanmıştır. Ayrıca, Olhan (1997) çalışmasında zeytin işletmelerinde ailelerin \%55.90'ının en yüksek oranla 3-4 kişiden oluştuğunu belirlerken Başaran (2011) ise üreticilerin \%56.80'inin 3-4 kişilik ailelerden oluştuğunu saptamıştır. İncelenen işletmelerde nüfus miktarının diğer çalışmalara çoğunlukla benzerlik gösterdiği ifade edilebilir. Tüm işletme grupları için işletme başına düşen nüfus içerisinde 15-49 yaş grubunun payının en yüksek düzeyde olduğu saptanırken bu grubun payı işletmeler 
ortalamasında \%41.80 olarak hesaplanmıştır. Yapılan benzer çalışmalarda 15-49 yaş aralığındaki nüfusun payı Anaç (2005)'a göre \%47.47, Özgürsoy (2006)'a göre \%70.00 ve Yapıcı (2006)'ya göre $\% 56.68$ olarak bulunmuştur. Nüfus yapısı cinsiyet bakımından incelendiğinde ise, erkek nüfusun kadın nüfusa üstünlüğü dikkat çekmekte ve erkek nüfusun ortalamada 1.92 kişi olduğu bulunurken toplam nüfus içerisindeki payı \%52.46'dır. Ayrıca, ortalamada faal nüfus oranı ise $\% 82.05$ olarak bulunmuştur.

Zeytin işletmelerinde nüfusun okur-yazarlık oranı ortalamada \%95.88 olarak hesaplanırken öğrenim süresi 6.13 yıl olarak bulunmuştur. İşletmelerde 7 yaş ve daha yukarı yaştaki nüfusun öğrenim düzeyi incelendiğinde nüfusun büyük çoğunluğunun ilkokul düzeyinde öğrenime sahip olduğu belirlenmiştir. İşletmeler ortalamasında ilkokul mezunu olanlar ortalama 2.28 kişi olup, \%64.95'lik bir paya sahiptirler. İşletmeler ortalamasında nüfusun öğrenim durumunu ortaokul (\%10.26), lise (\%9.12), okuryazar (\%6.55), okuryazar değil (\%3.99), üniversite (\%3.99) ve yüksekokul (\%1.14) mezunu nüfus takip etmektedir. Ayrıca, erkek nüfusun kadın nüfusa oranla öğrenim düzeyi daha yüksek bulunmuştur. Şöyle ki, işletmeler ortalamasında üniversite mezunu erkeklerin oranı \%6.01 iken, bu oran kadınlarda \%1.79 olarak hesaplanmış olup, okur-yazar olmayan nüfus oranı kadınlarda \%5.95 ve erkeklerde \%2.19 olarak saptanmıştır. Benzer çalışmada zeytin işletmelerinde hane halkı ortalama öğrenim süresi 4.50 yıl olarak bulunurken (Tunalığlu ve Gökçe, 2002), başka bir çalışmada işletmelerde ortalamada 7 yaş ve yukarı yaştaki nüfusun $\% 94.81$ 'inin okuma yazma bildiği ve \%62.01'inin ilkokul mezunu olduğu saptanmıştır (Anaç, 2005). Diğer bir çalışmada işletmeler ortalamasında nüfusun \%98.79'unun okuma yazma bildiği ve \%42.29'unun en yüksek oranla ilkokul mezunu olduğu belirlenmiştir (Yapıcı, 2006).

Araştırmada işletme yöneticisinin yaş ve öğrenim durumu özellikleri incelenmiş olup, ortalamada işletme yöneticisinin yaşı 54.40 yıl ve öğrenim süresi 5.82 yıl olarak hesaplanmıştır. Benzer çalışmalarda zeytin işletmelerinde işletmeci yöneticilerinin yaşları ve öğrenim süreleri ortalama olarak Tunalıoğlu ve Gökçe (2002)'ye göre 52.40 yıl ve 5.20 yıl, Gençler (2009)'e göre 55.10 yıl ve 6.73 yıl, Artukoglu ve ark. (2010)'na göre 57.60 yıl ve 6.20 yıl, Çukur ve ark. (2013)'na göre 57.55 yıl ve 5.87 yıl, Apaydın ve ark., (2014)'na göre 48.40 yıl ve 7.20 yıl olarak saptanmıştır. Başka bir çalışmada üreticilerin \%53.00'ünün 45-59 yaş arası olduğu ve \%55.10'unun ilköğretim mezunu olduğu belirlenmiştir (Özalp ve ark., 2016). Bu değerler araştırmada bulunan yaş ve öğrenim süreleri ile örtüşmektedir.

Tarım işletmelerinde enerji ve işgücünü sağlayan iki kaynak bulunduğu ifade edilmekte olup, bunlardan birisi işletmeci ve ailesi, diğeri de yabancı iş̧̧ilerdir (Karagölge, 1995). Tarımda, küçük aile işletmelerinde işgücünün asıl kaynağını aile fertleri oluşturduğu halde, işletmeler büyüdükçe aile işgücü yanında ücretli işçiye de yer vermek zorunluluğu doğmaktadır. Incelenen işletmelerde insan işgücü mevcudu belirlenirken aile işgücü potansiyeli ve kullanım durumu ile yabancı işgücü varlığı ortaya konulmuştur.

Zeytin işletmelerinde cinsiyete göre aile ve yabancı işgücü mevcudu ve kullanım durumu EiG ve oransal olarak Çizelge 1'de verilmiştir. İşletmelerde işgücünün esas kaynağını aile işgücü varlığı oluşturmaktadır. Potansiyel ve kullanılan aile işgücü işletme büyüklükleri itibariyle artmaktadır. Potansiyel aile işgücünün \%56.43'ünü ve kullanılan aile işgücünün ise $\% 62.58$ 'sini erkek işgücü oluşturmaktadır. İşletme dışında kullanılan aile işgücünün düşük düzeylerde olduğu ve yine tarımda değerlendirildiği belirlenirken bu durum 1. grup işletmelerde en yüksek düzeydedir. Şöyle ki, işletme dışında kullanılan aile işgücünün payı ortalamada \%1.41 iken, bu oran 1. grup işletmelerde \%4.77'dir. İşletmeler ortalamasında potansiyel aile işgücü 663.65 EIG olarak hesaplanırken bu işgücünün neredeyse yarısı (\%49.72) atıl durumdadır. Ayrıca, atıl aile işgücü oranının 3. grup işletmelerde en düşük düzeyde olduğu bulunmuştur.

İşletmelerde kullanılan toplam işgücü içerisinde aile işgücünün payı işletmeler ortalamasında \%73.28'dir ve işletme büyüklükleri itibariyle azalmaktadır. İşletmelerde daimi işgücü kullanımı söz konusu değilken, geçici işgücü kullanımı işletme genişlikleri itibariyle büyük artışlar göstermiştir. Kullanılan geçici işgücü mevcudu ortalamada 118.24 EiG'dir. Sonuç olarak işletmelerde aile işgücünün önemli bir bölümünün değerlendirilemediği ifade edilebilir.

Benzer çalışmada aile işgücünün \%60.70'ini erkek işgücünün oluşturduğu saptanmıştır (Anaç, 2005). Özgürsoy (2006) çalışmasında işletmeler ortalamasında mevcut aile işgücü potansiyelini 440 EIG olarak hesaplamış ve kullanılan işgücü oranının çok düşük (\%14.32) olduğunu belirlemiştir. Diğer bir çalışmada ise aile işgücünün $\% 70.86$ 'sının erkek işgücünden oluştuğu ve zeytin hasat dönemi, toprak sürümü ve budama işlerinde geçici yabancı işgücünün kullanıldığı belirlenmiştir (Yapıcı, 2006). 
Çizelge 1. Zeytin işletmelerinde işgücü mevcudu ve kullanım durumu. (ortalama ve \%)

\begin{tabular}{|c|c|c|c|c|c|c|c|c|c|}
\hline \multirow{3}{*}{\multicolumn{2}{|c|}{ işGÜcÜ YAPISI }} & \multicolumn{8}{|c|}{ iŞLETME GRUPLARI } \\
\hline & & \multicolumn{2}{|c|}{$1-15(37)$} & \multicolumn{2}{|c|}{$16-50(48)$} & \multicolumn{2}{|c|}{$51-+(67)$} & \multicolumn{2}{|c|}{ i̇şl. Ort. (152) } \\
\hline & & EiG & $\%$ & EIG & $\%$ & EiG & $\%$ & EiG & $\%$ \\
\hline \multirow{4}{*}{$\begin{array}{l}\text { Potansiyel } \\
\text { aile işgücü }\end{array}$} & Erkek & 322.30 & 58.24 & 343.75 & 55.27 & 425.37 & 56.38 & 374.51 & 56.43 \\
\hline & Kadın & 206.76 & 37.36 & 234.38 & 37.69 & 268.66 & 35.61 & 242.76 & 36.58 \\
\hline & Çocuk & 24.32 & 4.40 & 43.75 & 7.04 & 60.45 & 8.01 & 46.38 & 6.99 \\
\hline & TOPLAM & 553.38 & 100.00 & 621.88 & 100.00 & 754.48 & 100.00 & 663.65 & 100.00 \\
\hline \multirow{4}{*}{$\begin{array}{l}\text { İşletmede } \\
\text { kullanılan } \\
\text { aile işgücü }\end{array}$} & Erkek & 143.45 & 57.53 & 174.38 & 62.12 & 256.25 & 64.56 & 202.93 & 62.58 \\
\hline & Kadın & 104.29 & 41.82 & 106.35 & 37.88 & 139.53 & 35.16 & 120.48 & 37.15 \\
\hline & Çocuk & 1.62 & 0.65 & 0.00 & 0.00 & 1.12 & 0.28 & 0.89 & 0.27 \\
\hline & TOPLAM & 249.36 & 100.00 & 280.73 & 100.00 & 396.90 & 100.00 & 324.30 & 100.00 \\
\hline \multirow{3}{*}{$\begin{array}{l}\text { İşletme } \\
\text { dışında } \\
\text { kullanılan } \\
\text { aile işgücü }\end{array}$} & Tarımda & 24.59 & 93.11 & 3.33 & 100.00 & 4.31 & 100.00 & 8.94 & 95.31 \\
\hline & Tarım Dışında & 1.82 & 6.89 & 0.00 & 0.00 & 0.00 & 0.00 & 0.44 & 4.69 \\
\hline & TOPLAM & 26.41 & 100.00 & 3.33 & 100.00 & 4.31 & 100.00 & 9.38 & 100.00 \\
\hline \multirow{4}{*}{\multicolumn{2}{|c|}{$\begin{array}{l}\text { İşletmede dışında kullanılan aile } \\
\text { işgücü } \\
\text { İşletmede kullanılan aile işgücü } \\
\text { Kullanılmayan (atıl) aile işgücü } \\
\text { İşletmede potansiyel aile işgücü }\end{array}$}} & 26.41 & 4.77 & 3.33 & 0.54 & 4.31 & 0.57 & 9.38 & 1.41 \\
\hline & & 249.36 & 45.06 & 280.73 & 45.14 & 396.90 & 52.61 & 324.30 & 48.87 \\
\hline & & 277.61 & 50.17 & 337.82 & 54.32 & 353.27 & 46.82 & 329.97 & 49.72 \\
\hline & & 553.38 & 100.00 & 621.88 & 100.00 & 754.48 & 100.00 & 663.65 & 100.00 \\
\hline \multirow{4}{*}{$\begin{array}{l}\text { İşletmede } \\
\text { kullanılan } \\
\text { toplam } \\
\text { işgücü }\end{array}$} & Aile işgücü & 249.36 & 94.98 & 280.73 & 83.32 & 396.90 & 64.27 & 324.30 & 73.28 \\
\hline & $\begin{array}{l}\text { Geçici ücretli } \\
\text { işgücü }\end{array}$ & 13.18 & 5.02 & 56.22 & 16.68 & 220.69 & 35.73 & 118.24 & 26.72 \\
\hline & $\begin{array}{l}\text { Daimi ücretli } \\
\text { işgücü }\end{array}$ & 0.00 & 0.00 & 0.00 & 0.00 & 0.00 & 0.00 & 0.00 & 0.00 \\
\hline & TOPLAM & 262.54 & 100.00 & 336.95 & 100.00 & 617.59 & 100.00 & 442.54 & 100.00 \\
\hline
\end{tabular}

\section{Zeytin işletmelerinde arazi varlığı}

Diğer üretim faaliyetlerinden farklı olarak tarımsal üretimde arazi, üretimin en önemli ve vazgeçilmez unsurudur (Demirci, 1978). Zeytin işletmelerinde arazi varlığı ve tasarruf şekilleri Çizelge 2'de verilmiştir. Tüm işletme gruplarında mülk arazinin payı en yüksek durumdadır ve işletmeler ortalamasında \%92.88 olarak hesaplanmıştır. Toplam işletme arazisi içerisinde mülk arazinin payı işletme büyüklüklerine göre azalış göstermesine karşın kiraya tutulan arazi miktarı oransal olarak artış eğilimindedir. Zeytin işletmelerinde işletme başına düşen arazi miktarı 24.73 da ile 159.18 da arasında değişmekte olup, ortalamada 91.24 da'dır. Benzer çalışmalarda zeytin işletmelerinde ortalama arazi büyüklüğü ve toplam işletme arazisi içerisinde mülk arazi, kiraya ve ortağa tutulan arazi oranları Tunalıŏlu ve Gökçe (2002)'ye göre 63.10 da ve $\% 89.22, \% 6.50$ ve $\% 4.28$, Anaç, (2005)'a göre 39.74 da ve \%85.61, \%11.45 ve \%2.94, Yapıcı (2006)'ya göre 57.26 da ve \%99.27, \%0.73 ve $\% 0.00$, Gençler (2009)'e göre 105.21 da ve $\% 77.48$, $\% 18.18$ ve \%4.34, Seçer, (2012)'e göre ise 53.95 da ve $\% 48.14, \% 3.30$ ve $\% 2.51$ olarak hesaplanmıştır.

Çizelge 2. Zeytin işletmelerinde arazi mevcudu ve tasarruf şekli. (da, \%)

\begin{tabular}{|c|c|c|c|c|c|c|c|c|c|}
\hline \multirow{3}{*}{\multicolumn{2}{|c|}{ ARAZI UNSURLARI }} & \multicolumn{8}{|c|}{ IŞLETME GRUPLARI } \\
\hline & & \multicolumn{2}{|c|}{$1-15(37)$} & \multicolumn{2}{|c|}{$16-50(48)$} & \multicolumn{2}{|c|}{$51-+(67)$} & \multicolumn{2}{|c|}{ İşl. Ort. (152) } \\
\hline & & $\mathrm{Da}$ & $\%$ & $\mathrm{Da}$ & $\%$ & $\mathrm{Da}$ & $\%$ & $\mathrm{Da}$ & $\%$ \\
\hline \multirow{3}{*}{$\begin{array}{l}\text { MÜLK } \\
\text { ARAZi }\end{array}$} & Toplam mülk arazi & 24.14 & 97.61 & 44.44 & 93.22 & 147.09 & 92.40 & 84.74 & 92.88 \\
\hline & $\begin{array}{l}\text { Mülk araziden ortağa ve } \\
\text { kiraya verilen }\end{array}$ & 0.00 & 0.00 & 0.00 & 0.00 & 1.12 & 0.70 & 0.49 & 0.54 \\
\hline & İşletilen arazi & 24.14 & 97.61 & 44.44 & 93.22 & 145.97 & 91.70 & 84.25 & 92.34 \\
\hline \multicolumn{2}{|c|}{ Kiraya tutulan arazi } & 0.54 & 2.19 & 1.21 & 2.54 & 13.21 & 8.30 & 6.34 & 6.95 \\
\hline \multicolumn{2}{|c|}{ Ortağa tutulan arazi } & 0.05 & 0.20 & 2.02 & 4.24 & 0.00 & 0.00 & 0.65 & 0.71 \\
\hline \multicolumn{2}{|c|}{ TOPLAM IŞLETME ARAZISi } & 24.73 & 100.00 & 47.67 & 100.00 & 159.18 & 100.00 & 91.24 & 100.00 \\
\hline \multicolumn{2}{|c|}{ Parsel sayısı (adet) } & \multicolumn{2}{|c|}{3.54} & \multicolumn{2}{|c|}{5.83} & \multicolumn{2}{|c|}{8.82} & \multicolumn{2}{|c|}{6.59} \\
\hline \multicolumn{2}{|c|}{ Ortalama parsel alanı (da) } & \multicolumn{2}{|c|}{6.99} & \multicolumn{2}{|c|}{8.18} & \multicolumn{2}{|c|}{18.05} & \multicolumn{2}{|c|}{13.85} \\
\hline
\end{tabular}


İşletme arazilerinin parsel sayıları ve büyüklükleri incelendiğinde arazi büyüklüğü arttıkça ortalama parsel sayısının arttığı görülmektedir. Parsel sayısı işletmeler ortalamasında 6.59 adet ve parsel büyüklüğü 13.85 da'dır. Tunalığlu ve Gökçe (2002) çalışmalarında işletmeler ortalamasında parsel sayısını 5.00 adet ve parsel büyüklüğünü 12.60 da olarak saptamışlardır. Başka bir çalışmada ortalama parsel sayısı 8.59 adet olarak bulunmuştur (Gençler, 2009). Seçer (2012) ortalama parsel sayısını 5.00 adet ve parsel genişliğini ise 10.79 da olarak belirlemiştir. Apaydın ve ark., (2014) çalışmalarında ortalama zeytinlik parsel sayısını 3.70 adet olarak hesaplamıştır. Diğer bir çalışmada ortalama parsel sayısı 3.39 adet ve parsel genişliği 26.00 da olarak bulunmuştur (Özalp ve ark., 2016).
Zeytin işletmelerinde arazi nev'ileri ve dağılımı işletme grupları itibariyle Çizelge 3'te verilmiştir. Arazi nev'ileri içerisinde zeytin arazisi ilk sıradadır ve bunu tarla arazisi ve diğer meyvelik arazi izlemektedir. Toplam işletme arazisi içerisinde zeytinlik arazinin payı \%35.02 ve \%68.43 arasında değişmekte olup, bu oran işletmeler ortalamasında \%64.54 olarak hesaplanmıştır. Benzer çalışmalarda zeytin işletmelerinde toplam işletme arazisi içerisinde zeytin arazisinin payı Tunalıoğlu ve Gökçe (2002)'ye göre \%61.01, Anaç (2005)'a göre \%92.15, Yapıcı (2006)'ya göre \%84.37, Gençler (2009)'e göre $\% 80.57$, Artukoglu ve ark. (2012)'ye göre \%71.93, Seçer (2012)'e göre \%49.25 ve Çukur ve ark. (2013)'na göre \%97.16 olarak hesaplanmıştır.

Çizelge 3. Zeytin işletmelerinde arazi nev'ileri ve işletme arazisi içindeki dağılımı. (da, \%)

\begin{tabular}{|c|c|c|c|c|c|c|c|c|c|}
\hline \multirow{3}{*}{\multicolumn{2}{|c|}{ Arazi nev'ileri }} & \multicolumn{8}{|c|}{ iŞLETME GRUPLARI } \\
\hline & & \multicolumn{2}{|c|}{$1-15(37)$} & \multicolumn{2}{|c|}{$16-50(48)$} & \multicolumn{2}{|c|}{$51-+(67)$} & \multicolumn{2}{|c|}{ İşl. Ort. (152) } \\
\hline & & $\mathrm{Da}$ & $\%$ & $\mathrm{Da}$ & $\%$ & $\mathrm{Da}$ & $\%$ & $\mathrm{Da}$ & $\%$ \\
\hline \multirow{3}{*}{ Tarla arazisi } & Sulu & 5.87 & 23.73 & 6.69 & 14.03 & 24.82 & 15.59 & 14.48 & 15.87 \\
\hline & Kuru & 5.42 & 21.92 & 2.85 & 5.98 & 10.54 & 6.62 & 6.87 & 7.53 \\
\hline & Toplam & 11.29 & 45.65 & 9.54 & 20.01 & 35.36 & 22.21 & 21.35 & 23.40 \\
\hline \multirow{3}{*}{ Meyve arazisi } & Bağ & 1.70 & 6.88 & 3.86 & 8.10 & 8.93 & 5.61 & 5.57 & 6.10 \\
\hline & Meyvelik & 2.62 & 10.59 & 4.83 & 10.13 & 1.28 & 0.80 & 2.73 & 2.99 \\
\hline & Toplam & 4.32 & 17.47 & 8.69 & 18.23 & 10.21 & 6.41 & 8.30 & 9.09 \\
\hline \multirow{3}{*}{ Zeytin arazisi } & Kuru & 7.77 & 31.42 & 19.01 & 39.88 & 76.29 & 47.93 & 41.52 & 45.51 \\
\hline & Sulu & 0.89 & 3.60 & 8.72 & 18.29 & 32.63 & 20.50 & 17.36 & 19.03 \\
\hline & Toplam & 8.66 & 35.02 & 27.73 & 58.17 & 108.92 & 68.43 & 58.88 & 64.54 \\
\hline \multicolumn{2}{|l|}{ Sebzelik arazi } & 0.46 & 1.86 & 1.25 & 2.62 & 4.69 & 2.95 & 2.57 & 2.82 \\
\hline \multicolumn{2}{|l|}{ Ağaçlık arazi } & 0.00 & 0.00 & 0.00 & 0.00 & 0.00 & 0.00 & 0.00 & 0.00 \\
\hline \multicolumn{2}{|l|}{ Nadas } & 0.00 & 0.00 & 0.46 & 0.97 & 0.00 & 0.00 & 0.14 & 0.15 \\
\hline \multicolumn{2}{|c|}{ Toplam işletme arazisi } & 24.73 & 100.00 & 47.67 & 100.00 & 159.18 & 100.00 & 91.24 & 100.00 \\
\hline
\end{tabular}

\section{Zeytin işletmelerinde sermaye yapısı}

Bir işletmenin optimal olarak çalışabilmesi için, o işletmede çeşitli sermaye unsurlarının belirli oranlarda bulunması gerekmektedir. Sermaye miktar ve bileşiminin incelenmesi, işletmelerin sahip oldukları envanter çıkarma, amortisman hesaplama ve işletme analizleri gibi ekonomik değerlerin belirlenmesinde de kolaylık sağlamaktadır (Aras, 1988).

$\mathrm{Bu}$ araştırmada sermaye miktar ve bileşimlerinin ortaya konulmasında sermayenin fonksiyonlarına göre sınıflandırma şekli esas alınmış ve sermaye aktif ve pasif sermaye olmak üzere iki grupta değer ve oransal olarak Çizelge 4'de verilmiştir.

Çizelge 4 incelendiğinde aktif sermaye toplam değerinin işletme büyüklüğü ile artan bir seyir göstermesine karşın işletme arazisi dekarına düşen aktif sermaye değeri ile işletme büyüklükleri arasında ters bir ilişki olduğu görülmektedir. Aktif sermaye içerisinde arazi sermayesinin payı oldukça yüksek olup, işletmeler ortalamasında \%93.13'tür. Tüm işletme grupları içerisinde en yüksek payı toprak sermayesi alırken bitki ve bina sermayesi diğer önemli aktif sermaye unsurlarıdır. İşletme sermayesinin aktif sermayeden aldığı paylar \%6.18 ile \%11.34 arasında değişmektedir ve ortalamada $\% 6.88^{\prime}$ lik pay ile düşük düzeydedir. İşletme sermayesi unsurlarının değerleri işletme grupları itibariyle artış gösterirken aktif sermayeden aldıkları paylar azalmaktadır.

Bir tarım işletmesinde aktif sermayenin dağılımı, toprak sermayesi \%25, bina sermayesi $\% 25$, hayvan sermayesi $\% 25$, alet-makine sermayesi $\% 10$, malzeme mühimmat sermayesi \%10 ve para sermayesi \%5 şeklinde olması istenmektedir (Erkuş ve ark., 1995). Yani, rasyonel çalışan işletmelerde aktif sermayenin yarısını çiftlik sermayesi, diğer yarısını da işletme sermayesinin oluşturması beklenmektedir (Yapıcı, 2006). 
Çizelge 4. Zeytin işletmelerinde aktif sermaye unsurları değeri ve oransal dağılımı. (TL, \%)

\begin{tabular}{|c|c|c|c|c|c|}
\hline \multirow{2}{*}{\multicolumn{2}{|c|}{ SERMAYE UNSURLARI }} & \multicolumn{4}{|c|}{ iŞLETME GRUPLARI } \\
\hline & & $\begin{array}{c}1-15 \\
(37)\end{array}$ & $\begin{array}{c}16-50 \\
(48)\end{array}$ & $51-+(67)$ & $\begin{array}{l}\text { İşl. Ort. } \\
\text { (152) }\end{array}$ \\
\hline \multicolumn{6}{|c|}{ AKTIF SERMAYE UNSURLARI (TL) } \\
\hline \multirow{6}{*}{$\begin{array}{l}\text { ARAZi } \\
\text { SERMAYESI }\end{array}$} & Toprak sermayesi & $\begin{array}{c}175 \\
932.43\end{array}$ & 370438.02 & $\begin{array}{c}1120 \\
152.99\end{array}$ & 653557.73 \\
\hline & Arazi ıslahı sermayesi & 6500.68 & 12108.12 & 21440.30 & 14856.68 \\
\hline & Bina sermayesi & 49851.08 & 57607.91 & 83538.88 & 67149.83 \\
\hline & Bitki sermayesi & 19080.74 & 39355.76 & 114103.84 & 67368.56 \\
\hline & Tarla demirbaşı sermayesi & 1666.19 & 586.92 & 3895.97 & 2308.23 \\
\hline & Arazi sermayesi toplamı & $\begin{array}{c}253 \\
031.12 \\
\end{array}$ & 480096.73 & $\begin{array}{c}1343 \\
131.98 \\
\end{array}$ & 805241.03 \\
\hline \multirow{5}{*}{$\begin{array}{l}\text { IŞLETME } \\
\text { SERMAYESi }\end{array}$} & Sabit işletme Alet-makine serm. & 15923.65 & 20404.69 & 41661.57 & 28683.72 \\
\hline & sermayesi Hayvan sermayesi & 11792.16 & 12107.60 & 26225.90 & 18254.01 \\
\hline & Malz. müh. serm. & 2292.20 & 4001.87 & 10013.10 & 6235.39 \\
\hline & $\begin{array}{l}\text { işletme } \\
\text { sermayesi } \quad \text { Para sermayesi }\end{array}$ & 2359.86 & 3271.57 & 10587.01 & 6274.21 \\
\hline & İşletme sermayesi toplamı & 32367.88 & 39785.73 & 88487.57 & 59447.33 \\
\hline \multirow{2}{*}{\multicolumn{2}{|c|}{$\begin{array}{l}\text { AKTIF SERMAYE TOPLAMI } \\
\text { İşletme arazisi dekarına düşen aktif sermaye } \\
\text { (TL/da) }\end{array}$}} & $\begin{array}{c}285 \\
399.00\end{array}$ & 519882.47 & $\begin{array}{c}1431 \\
619.56\end{array}$ & 864688.36 \\
\hline & & 11540.60 & 10905.86 & 8993.71 & 9477.08 \\
\hline \multicolumn{6}{|c|}{$\begin{array}{l}\text { PASIF SERMAYE UNSURLARI (TL) } \\
\end{array}$} \\
\hline \multirow{3}{*}{$\begin{array}{l}\text { YABANCI } \\
\text { SERMAYE }\end{array}$} & Borçlar & 11693.24 & 16001.67 & 21785.90 & 17502.53 \\
\hline & $\begin{array}{l}\text { Kiraya ve ortağa tutulan arazi } \\
\text { değeri }\end{array}$ & 4729.73 & 21968.75 & 84988.81 & 45550.99 \\
\hline & TOPLAM & 16422.97 & 37970.42 & 106774.71 & 63053.52 \\
\hline \multicolumn{2}{|l|}{ ÖZ SERMAYE } & $\begin{array}{c}268 \\
976.03\end{array}$ & 481912.05 & $\begin{array}{c}1324 \\
844.85\end{array}$ & 801634.84 \\
\hline \multicolumn{2}{|c|}{ PASIF SERMAYE TOPLAMI } & $\begin{array}{c}285 \\
399.00\end{array}$ & 519882.47 & $\begin{array}{c}1431 \\
619.56\end{array}$ & 864688.36 \\
\hline \multicolumn{2}{|c|}{$\begin{array}{l}\text { İşletme arazisi dekarına düşen pasif sermaye } \\
\text { (TL/da) }\end{array}$} & 11540.60 & 10905.86 & 8993.72 & 9477.08 \\
\hline
\end{tabular}

Araştırmada işletme gruplarında ve işletmeler ortalamasında; arazi sermayesi ve işletme sermayesi arasında büyük farklar olduğu tespit edilmiştir. Çiftlik sermayesi ile bu sermayenin verimli kullanılmasını sağlayan işletme sermayesi arasındaki büyük dengesizlik, işletmelerin rasyonel çalışmasını engellemektedir (Yapıcı, 2006). Aktif sermaye içerisinde çiftlik sermayesinin oranının bu kadar yüksek olmasının sebebi toprak ve bitki sermayesi oranının çok yüksek olması, bunun karşın işletme sermaye unsurlarının oranının da yetersiz olmasıdır.

Benzer çalışmalarda da aktif sermaye unsurlarının rasyonel dağılım göstermediği belirlenmiştir. Şöyle ki, aktif sermaye içerisinde çiftlik sermayesi ve işletme sermayesi oranları sırasıyla Anaç (2005)'a göre \%97.23 ve \%2.77, Özgürsoy (2006)'a göre \%88.80 ve \%11.20, Yapıcı (2006)'ya göre \%94.79 ve \%5.21'dir.

Tarım işletmelerinde üretim amacıyla bulundurulan aktif sermayenin temininde kullanılan kaynaklar, işletmenin pasif sermayesini oluşturmaktadır. Pasif sermaye, temin edildikleri kaynaklar itibariyle öz sermaye ve yabancı sermaye olmak üzere iki gruba ayrılmaktadır. Öz sermaye, aktif sermayeden yabancı kaynakların çıkarılmasıyla elde edilmektedir (Erkuş ve ark., 1995).

Yabancı sermayeyi oluşturan unsurlar işletmelerin gerçek borçları ile kiraya ve ortağa tutulan arazi değerinden oluşan itibari borçlarıdır. Çizelge 4'ten de izlenebileceği gibi işletmelerin gerçek borçları işletme büyüklüğüne paralel olarak azalış göstermekte olup, pasif sermaye içerisindeki payı ortalamada \%2.02'dir. Benzer çalışmalarda pasif sermaye içerisinde borçların payı Anaç (2005)'e göre \%0.35 ve Yapıcı (2006)'ya göre \%0.19 olarak hesaplanmıştır. İşletmelerde pasif sermaye içerisinde itibari borçların payı \%1.66 ile \%5.94 arasında değişmekte olup, işletmeler ortalamasında \%5.27'dir. Benzer çalışmada itibari borçların pasif sermayeden \%8.00 oranında pay aldığı belirlenmiştir (Anaç, 2005). Diğer bir çalışmada 
itibari borçların kiraya tutulan arazi değerinden oluştuğu ve pasif sermayeden $\% 0.29$ oranında pay aldığı bulunmuştur (Yapıcı, 2006).

Çizelge 4 (Devamı). Zeytin işletmelerinde aktif sermaye unsurları değeri ve oransal dağılımı. (TL, \%)

\begin{tabular}{|c|c|c|c|c|c|}
\hline & \multirow[b]{2}{*}{ SERMAYE UNSURLARI } & \multicolumn{4}{|c|}{ IŞLETME GRUPLARI } \\
\hline & & $\begin{array}{c}1-15 \\
(37)\end{array}$ & $\begin{array}{c}16-50 \\
(48)\end{array}$ & $51-+(67)$ & $\begin{array}{l}\text { İşl. Ort. } \\
\text { (152) }\end{array}$ \\
\hline \multicolumn{6}{|c|}{ AKTIF SERMAYE UNSURLARI (\%) } \\
\hline \multirow{6}{*}{$\begin{array}{l}\text { ARAZi } \\
\text { SERMAYESI }\end{array}$} & Toprak sermayesi & 61.64 & 71.25 & 78.24 & 75.58 \\
\hline & Arazi ıslahı sermayesi & 2.28 & 2.33 & 1.50 & 1.72 \\
\hline & Bina sermayesi & 17.47 & 11.08 & 5.84 & 7.76 \\
\hline & Bitki sermayesi & 6.69 & 7.57 & 7.97 & 7.79 \\
\hline & Tarla demirbaşı sermayesi & 0.58 & 0.12 & 0.27 & 0.27 \\
\hline & Arazi sermayesi toplamı & 88.66 & 92.35 & 93.82 & 93.12 \\
\hline \multirow{5}{*}{$\begin{array}{l}\text { IŞLETME } \\
\text { SERMAYESi }\end{array}$} & Sabit işletme Alet-makine serm. & 5.58 & 3.92 & 2.91 & 3.32 \\
\hline & Hayvan sermayesi & 4.13 & 2.33 & 1.83 & 2.11 \\
\hline & Malz. müh. serm. & 0.80 & 0.77 & 0.70 & 0.72 \\
\hline & $\begin{array}{l}\text { işletme } \\
\text { sermayesi } \quad \text { Para sermayesi }\end{array}$ & 0.83 & 0.63 & 0.74 & 0.73 \\
\hline & İşletme sermayesi toplamı & 11.34 & 7.65 & 6.18 & 6.88 \\
\hline \multicolumn{2}{|c|}{ AKTIF SERMAYE TOPLAMI } & 100.00 & 100.00 & 100.00 & 100.00 \\
\hline \multicolumn{6}{|c|}{$\begin{array}{l}\text { PASIF SERMAYE UNSURLARI (\%) } \\
\end{array}$} \\
\hline \multirow{3}{*}{$\begin{array}{l}\text { YABANCI } \\
\text { SERMAYE }\end{array}$} & Borçlar & 4.09 & 3.08 & 1.52 & 2.02 \\
\hline & $\begin{array}{l}\text { Kiraya ve ortağa tutulan arazi } \\
\text { değeri }\end{array}$ & 1.66 & 4.22 & 5.94 & 5.27 \\
\hline & TOPLAM & 5.75 & 7.30 & 7.46 & 7.29 \\
\hline \multicolumn{2}{|c|}{ ÖZ SERMAYE } & 94.25 & 92.70 & 92.54 & 92.71 \\
\hline \multirow{3}{*}{\multicolumn{2}{|c|}{$\begin{array}{l}\text { PASIF SERMAYE TOPLAMI } \\
\text { İşletme arazisi dekarına düşen öz sermaye (TL/da) } \\
\text { Öz sermayenin aktif sermayeye oranı (\%) }\end{array}$}} & 100.00 & 100.00 & 100.00 & 100.00 \\
\hline & & 10876.51 & 10109.34 & 8322.94 & 8786.00 \\
\hline & & 94.25 & 92.70 & 92.54 & 92.71 \\
\hline
\end{tabular}

İşletmenin kendi kaynaklarından oluşan öz sermaye, işletme tarafından sürekli olarak kullanılabilecek bir sermayedir (Anaç, 2005). Zeytin işletmelerinde öz sermaye değeri işletme büyüklükleri itibariyle artış göstermesine karşın işletme arazisine düşen öz sermaye değeri ile işletme büyüklükleri arasında ters ilişki söz konusudur. Öz sermayenin aktif sermayeye oranı işletme gruplarında \%92.70 ile \%94.25 arasında değişmekte olup, ortalamada \%92.71 olarak hesaplanmıştır. Benzer çalışmalarda öz sermayenin pasif sermaye içerisinde payı işletmeler ortalamasında Anaç (2005)'a göre \%91.65, Özgürsoy (2006)'a göre \%99.10 ve Yapıcı (2006)'ya göre \%99.52'dir.

\section{Zeytin işletmelerinde ham zeytin, işlenmiş zeytin (sofralık) ve zeytinyağı üretiminde masraflar ve maliyetler}

Zeytin işletmelerinde ham zeytin üretim maliyeti unsurlarına ilişkin bilgiler değer ve oransal olarak Çizelge 5'de verilmiştir. Dekara üretim maliyeti unsurlarının büyük çoğunluğu ile zeytin verimi ve zeytinin kilogram maliyeti arazi büyüklüğü itibariyle azalış göstermektedir. Dekara zeytin verimi işletmeler ortalamasında $401.66 \mathrm{~kg}$ olarak bulunmuştur. İşletmeler ortalamasında $1 \mathrm{~kg}$ zeytinin maliyeti 2.10 TL olarak saptanmış olup, 1. grup işletmeler zeytini en yüksek maliyetle üretmektedirler.

İşletmeler ortalamasında değişken masraflar toplam masrafların neredeyse yarısını (\%47.17) oluştururken değişken masraflar içerisinde hasat ve bakım masrafları en önemli masraf unsurlarıdır.

İşletme grupları itibariyle toplam masraflar içerisinde değişken masrafların oranı 1. grup işletmelerde en yüksek oranda bulunurken işletmeler ortalamasına benzer şekilde hasat (\%20.65) ve bakım (\%15.68) masraflarının en yüksek payı aldığı bulunmuştur. İşletmeler ortalamasında sabit masraflar ise toplam masrafların \%52.83'ünü oluşturmakta olup, sabit masraf unsurlarından arazi kirası (\%37.70) ve amortismanlar (\%7.90) en önemli masraf kalemleridir. 
Çizelge 5. Zeytin işletmelerinde ham zeytin üretim maliyeti ve unsurları

\begin{tabular}{|c|c|c|c|c|}
\hline \multirow{2}{*}{ UNSURLAR } & \multicolumn{4}{|c|}{ IŞLETME GRUPLARI } \\
\hline & $1-15(37)$ & $16-50(48)$ & $51-+(67)$ & İşl.Ort. (152) \\
\hline \multicolumn{5}{|l|}{ MALIYET UNSURLARI (TL/da) } \\
\hline a- Toprak işleme & 37.52 & 23.84 & 20.48 & 25.69 \\
\hline b- Çapalama ve dip temizliği & 41.93 & 20.55 & 17.07 & 24.22 \\
\hline c- Budama ve artıkların toplanması & 99.30 & 56.45 & 41.27 & 60.19 \\
\hline 1. TOPLAM BAKIM MASRAFLARI $(a+b+c)$ & 178.75 & 100.84 & 78.82 & 110.10 \\
\hline 2. Gübreleme masrafları & 83.07 & 55.09 & 53.64 & 61.26 \\
\hline 3. Illaçlama masrafları & 37.28 & 28.77 & 17.78 & 26.00 \\
\hline 4. Sulama masrafları & 14.45 & 19.83 & 11.92 & 15.03 \\
\hline 5. Hasat masrafları & 235.42 & 131.74 & 98.87 & 142.49 \\
\hline 6. Alet-makine tamir bakım masrafı & 14.50 & 11.80 & 7.80 & 10.69 \\
\hline 7. Koruma masrafı & 0.30 & 1.79 & 0.92 & 1.04 \\
\hline 8. Döner sermaye faizi & 48.03 & 29.42 & 22.84 & 31.05 \\
\hline 9. Diğer & 0.00 & 0.16 & 0.00 & 0.05 \\
\hline A. TOPLAM DEĞiŞKEN MASRAFLAR & 611.79 & 379.45 & 292.59 & 397.71 \\
\hline 1. Genel idare giderleri & 18.35 & 11.38 & 8.78 & 11.93 \\
\hline 2. Arazi kirası & 315.20 & 374.22 & 278.99 & 317.88 \\
\hline 3. Arazi vergisi & 6.30 & 7.48 & 5.58 & 6.36 \\
\hline 4. Amortisman (bina+alet-makine) & 129.32 & 64.56 & 33.44 & 66.58 \\
\hline 5. Tesisin yıllık amortisman payı & 33.70 & 22.84 & 18.66 & 23.64 \\
\hline 6. Tesisin yıllık amortisman faizi & 21.54 & 16.20 & 14.22 & 16.63 \\
\hline 7. Ürün sigortası & 1.14 & 3.79 & 0.75 & 1.80 \\
\hline 8. Diğer & 2.70 & 0.00 & 0.05 & 0.68 \\
\hline B. TOPLAM SABIT MASRAFLAR & 528.16 & 500.48 & 360.46 & 445.50 \\
\hline C. TOPLAM ÜRETIM MASRAFLARI (A+B) & 1139.95 & 879.93 & 653.05 & 843.21 \\
\hline D. Ham Zeytin Ortalama Verimi (Kg) & 459.32 & 395.67 & 374.11 & 401.66 \\
\hline E. HAM ZEYTIN MALIYETI (TL/KG) (C/D) & 2.48 & 2.22 & 1.75 & 2.10 \\
\hline \multicolumn{5}{|l|}{ MALIYET UNSURLARI (\%) } \\
\hline a- Toprak işleme & 3.29 & 2.71 & 3.14 & 3.05 \\
\hline b- Çapalama ve dip temizliği & 3.68 & 2.34 & 2.61 & 2.87 \\
\hline c- Budama ve artıkların toplanması & 8.71 & 6.42 & 6.32 & 7.14 \\
\hline 1. Toplam bakım masrafları $(a+b+c)$ & 15.68 & 11.46 & 12.07 & 13.06 \\
\hline 2. Gübreleme masrafları & 7.29 & 6.26 & 8.21 & 7.27 \\
\hline 3. İlaçlama masrafları & 3.27 & 3.27 & 2.72 & 3.08 \\
\hline 4. Sulama masrafları & 1.27 & 2.25 & 1.83 & 1.78 \\
\hline 5. Hasat masrafları & 20.65 & 14.97 & 15.14 & 16.90 \\
\hline 6. Alet-makine tamir bakım masrafı & 1.27 & 1.34 & 1.19 & 1.27 \\
\hline 7. Koruma masrafı & 0.03 & 0.20 & 0.14 & 0.12 \\
\hline 8. Döner sermaye faizi & 4.21 & 3.34 & 3.50 & 3.68 \\
\hline 9. Diğer & 0.00 & 0.02 & 0.00 & 0.01 \\
\hline A. TOPLAM DEĞiŞKEN MASRAFLAR & 53.67 & 43.12 & 44.80 & 47.17 \\
\hline 1. Genel idare giderleri & 1.61 & 1.29 & 1.34 & 1.41 \\
\hline 2. Arazi kirası & 27.65 & 42.53 & 42.72 & 37.70 \\
\hline 3. Arazi vergisi & 0.55 & 0.85 & 0.85 & 0.75 \\
\hline 4. Amortisman (bina+alet-makine) & 11.34 & 7.34 & 5.12 & 7.90 \\
\hline 5. Tesisin yıllık amortisman payı & 2.96 & 2.60 & 2.86 & 2.80 \\
\hline 6. Tesisin yıllık amortisman faizi & 1.89 & 1.84 & 2.18 & 1.97 \\
\hline 7. Ürün sigortası & 0.10 & 0.43 & 0.11 & 0.21 \\
\hline 8. Diğer & 0.24 & 0.00 & 0.01 & 0.08 \\
\hline B. TOPLAM SABIT MASRAFLAR & 46.33 & 56.88 & 55.20 & 52.83 \\
\hline C. TOPLAM ÜRETIM MASRAFLARI (A+B) & 100.00 & 100.00 & 100.00 & 100.00 \\
\hline
\end{tabular}


Ayrıca, toplam masraflar içerisinde sabit masrafların payı 2. grup işletmelerde en yüksek durumdadır. Bunun nedeni 2. grup işletmelerde arazi kirası değerinin diğer gruplardaki işletmelere göre daha yüksek olmasıdır. Benzer çalışmalarda zeytin üretiminde önemli masraf kalemlerinden birinin Lambarraa ve ark., (2007)'na göre işgücü masrafı olduğu belirtilirken Artukoglu ve ark., (2010) çalışmalarında toplam masraflar içerisinde işgücü masrafının oranını \%19.31 ile en yüksek düzeyde olduğunu tespit etmişlerdir. Başka bir çalışmada değişken masraflar içerisinde hasat masrafı (\%29.55), sabit masraflar içerisinde ise arazi kirasının (\%85.18) en önemli masraf unsuru olduğu bulunmuştur (Artukoglu ve ark., 2012). Diğer bir çalışmada değişken masraflardan hasat işçiliği $(\% 25,26)$ ve sabit masraflardan arazi sermayesi faiz karşıı̆̆ının (\%21.81) en önemli masraf unsurları olduğu belirlenmiştir (Özalp ve ark., 2016).

Araştırmada sadece pazara yönelik olarak sofralık işlenmiş zeytin ürünü üreten işletmelere göre maliyetler hesaplanmış olup, işlenmiş zeytin üretim maliyeti ve unsurları değer ve oransal olarak Çizelge 6'da sunulmuştur. İşlenmiş zeytin üretim maliyeti işletme büyüklüklerine göre azalan bir seyir göstermektedir. İşlenmiş zeytini $4.29 \mathrm{TL} / \mathrm{kg}$ ile en yüksek maliyetle 1 . grup işletmeler üretirken işletmeler ortalamasında bu değer $3.35 \mathrm{TL} / \mathrm{kg}^{\prime}$ dır. İşletmeler ortalamasında zeytin işleme masrafları içerisinde fire masrafları \%73.11'lik pay ile ilk sırayı alırken bunu \%14.18'lik pay ile işçilik masrafı, \%4.94'lük paylar ile elektrik, su vb. masraflar ile tuz, kimyasal madde vb. masraflar ve $\% 2.86$ 'lık pay ile diğer masraflar izlemektedir. Karslı (2006) çalışmasında zeytin işletmelerinde işletme masrafları içerisinde hasat ve nakliye masraflarının $\% 50.13$ 'lük en yüksek pay ile en önemli masraf unsuru olduğunu belirlerken Tiryakioğlu (2011) çalışmasında sofralık zeytin işletmelerinde üretim masrafları içerisinde hammadde (zeytin) alımı (\%50.00) ve iş̧̧ilik ücretlerini (\%16.00) en önemli masraf kalemleri olarak bulmuştur.

Çizelge 6. Zeytin işletmelerinde işlenmiş zeytin üretim maliyeti ve unsurları

\begin{tabular}{|c|c|c|c|c|}
\hline \multirow{2}{*}{ UNSURLAR } & \multicolumn{4}{|c|}{ IŞLETME GRUPLARI } \\
\hline & $1-15(2)$ & $16-50(3)$ & $51-+(6)$ & İşl. Ort. (11) \\
\hline \multicolumn{5}{|l|}{ MALIYET UNSURLARI (TL/da) } \\
\hline İşçilik Masrafı & 20.26 & 40.38 & 38.55 & 35.73 \\
\hline Elektrik, su vb. masraflar & 4.97 & 16.46 & 12.93 & 12.44 \\
\hline Tuz, kimyasal madde vb. masraflar & 7.61 & 23.59 & 8.35 & 12.37 \\
\hline Fire değeri & 226.50 & 136.28 & 194.10 & 184.22 \\
\hline Diğer masraflar & 0.00 & 23.58 & 1.43 & 7.21 \\
\hline Toplam İşlenmiş Zeytin İşleme Masrafları (A) & 259.34 & 240.28 & 255.36 & 251.97 \\
\hline İşlenmiş zeytine ayrılan ham zeytin miktarı & 293.87 & 289.55 & 383.86 & 341.77 \\
\hline İşlenmiş Zeytine Ayrılan Ham Zeytin Değeri (B) & 688.79 & 614.93 & 620.17 & 631.22 \\
\hline İşlenmiş Zeytin Üretim Masrafları (A+B) & 948.13 & 855.22 & 875.53 & 883.19 \\
\hline İşlenmiş Zeytin Üretim Miktarı (C) & 221.05 & 235.15 & 292.44 & 263.84 \\
\hline İşlenmiş Zeytin Üretim Maliyeti (TL/Kg) $(\mathrm{A}+\mathrm{B}) / \mathrm{C}$ & 4.29 & 3.64 & 2.99 & 3.35 \\
\hline \multicolumn{5}{|l|}{ MALIYET UNSURLARI (\%) } \\
\hline İşçilik masrafı & 7.81 & 16.80 & 15.10 & 14.18 \\
\hline Elektrik, su vb. masraflar & 1.92 & 6.85 & 5.06 & 4.94 \\
\hline Tuz, kimyasal madde vb. masraflar & 2.93 & 9.82 & 3.27 & 4.91 \\
\hline Fire değeri & 87.34 & 56.72 & 76.01 & 73.11 \\
\hline Diğer masraflar & 0.00 & 9.81 & 0.56 & 2.86 \\
\hline Toplam İşlenmiş Zeytin İşleme Masrafları (A) & 100.00 & 100.00 & 100.00 & 100.00 \\
\hline
\end{tabular}

Zeytin işletmelerinde zeytinyağı üretim maliyeti ve unsurları değer ve oransal olarak Çizelge 7'de verilmiştir. İşletmelerde değer olarak zeytinyağı üretim masrafları arazi büyüklükleri bakımından artan bir seyir gösterirken zeytinyağı üretim maliyetleri azalış eğilimindedir. İşletmeler ortalamasında zeytinyağı üretim masrafları içerisinde zeytinyağına ayrılan ham zeytin değeri
\%94.27 ve zeytinyağına işleme masrafları \%5.73 pay almaktadır. Zeytinyağına işleme masrafları içerisinde yağ işleme masrafı arazi büyüklükleri itibariyle oransal olarak artış gösterirken taşıma ve depolama masrafları azalış eğilimdedir. İşletmelerde $1 \mathrm{~kg}$ zeytinyağı $8.74 \mathrm{TL}$ ile $11.76 \mathrm{TL}$ arasında bir masrafla üretilirken bu değer işletmeler ortalamasında 9.13 TL olarak hesaplanmıştır. 
Çizelge 7. Zeytin işletmelerinde zeytinyağı üretim maliyeti ve unsurları

\begin{tabular}{|c|c|c|c|c|}
\hline \multirow{2}{*}{ UNSURLAR } & \multicolumn{4}{|c|}{ iŞLETME GRUPLARI } \\
\hline & $1-15(28)$ & $16-50(33)$ & $51-+(56)$ & İşl. Ort. (117) \\
\hline \multicolumn{5}{|l|}{ MALIYET UNSURLARI (TL/da) } \\
\hline Taşıma ve depolama masrafları & 44.88 & 83.24 & 154.86 & 108.34 \\
\hline Yağ işleme masrafı & 343.56 & 861.09 & 2730.15 & 1631.83 \\
\hline Zeytinyağı İşleme Masrafları (A) & 388.44 & 944.33 & 2885.01 & 1740.17 \\
\hline Zeytinyağına ayrılan ham zeytin miktarı (kg) & 3100.89 & 8230.30 & 27739.46 & 16340.47 \\
\hline Zeytinyağına Ayrılan Ham Zeytin Değeri (B) & 6758.17 & 16843.75 & 46571.29 & 28658.67 \\
\hline Zeytinyağı Üretim Masrafları (A+B) & 7146.61 & 17788.08 & 49456.30 & 30398.84 \\
\hline Zeytinyağı Üretim Miktarı (C) & 607.95 & 1691.82 & 5656.77 & 3330.18 \\
\hline Zeytinyağı Üretim Maliyeti (TL/Kg) (A+B)/C & 11.76 & 10.51 & 8.74 & 9.13 \\
\hline \multicolumn{5}{|l|}{ MALIYET UNSURLARI (\%) } \\
\hline Taşıma ve depolama masrafları & 0.63 & 0.47 & 0.31 & 0.36 \\
\hline Yağ işleme masrafı & 4.81 & 4.84 & 5.52 & 5.37 \\
\hline Zeytinyağı İşleme Masrafları (A) & 5.44 & 5.31 & 5.83 & 5.73 \\
\hline Zeytinyağına ayrılan ham zeytin miktarı & 3100.89 & 8230.30 & 27739.46 & 16340.47 \\
\hline Zeytinyağına Ayrılan Ham Zeytin Değeri (B) & 94.56 & 94.69 & 94.17 & 94.27 \\
\hline Zeytinyağı Üretim Masrafları (A+B) & 100.00 & 100.00 & 100.00 & 100.00 \\
\hline
\end{tabular}

\section{Sorunlar ve beklentiler}

Araştırmada zeytin işletmelerinde üretim aşamasında karşılaşılan sorunlar incelenmiş olup, işletmelerde üretim uygulamaları içerisinde toprak hazırlığı, gübreleme, sulama ve hasat işlemlerinde maliyetlerin yüksekliği ve işgücü yetersizliğinin en önemli sorunlar olduğu belirlenmiştir. Maliyetlerin yüksekliği ve işgücü yetersizliği sorunları toprak hazırlığı için sırasıyla \%53.28 ve \%19.74, gübreleme için \%45.39 ve \%18.42, sulama için $\% 17.10$ ve $\% 7.24$ oranında pay alırken hasat işlemleri ise $\% 42.76$ ve \%26.97 oranında pay almıştır. Ilaçlamada ise maliyetlerin yüksekliği (\%33.55) ve uygulamada yetersiz bilgi (\%21.71) üreticilerin karşılaştığı en önemli sorunlardır. Benzer çalışmada zeytin bakımında en önemli sorunların ilaçlama ve gübreleme olduğu belirlenmiştir (Tunalığlu ve Gökçe, 2002). Başka bir çalışmada zeytin üreticilerinin en önemli sorunlarının sulama, hasat ve gübreleme olduğu bulunmuştur (Seçer, 2012). Apaydın ve ark., (2014) çalışmalarında zeytin işletmelerinde üretim ile ilgili en önemli sorunların devlet desteklerinin yetersizliği ve işçi ücretlerinin yüksekliği olduğunu tespit etmişlerdir. Diğer bir çalışmada ise maliyetlerin zeytincilik faaliyetini olumsuz etkilediği belirtilirken sürüm, yabancı ot zararı, zeytin hastalıkları ve ulaşım güçlüğünün en önemli sorunlar olduğu ifade edilmiştir (Ilgar, 2016).

Zeytin üreticilerinin devletten bir takım beklentileri bulunmaktadır. Üretim aşamasında halkalı leke, verticillium solgunluğu ve dal kanseri başta olmak üzere zeytin hastalıklarının önlenmesi, zeytinliklerin eskiden olduğu gibi tekrar uçakla toplu ilaçlamasının yapılması, yabani hayvan zararlarına önlem alınması, arazi sulama problemlerine yer altı ve üstü kaynakları ile çözüm sağlanması, hasat kayıpları ve zeytinlerin bekletilmesi nedeniyle yaşanan kayıpların önlenmesi, periyodisite ve verim düşüklüğünün nedenlerinin araştırılması ve çözüm bulunması, dönemsel işgücü ihtiyacının karşılanmasına yönelik tedbirlerin geliştirilmesi, girdi fiyatlarındaki pahalılığın vergi muafiyeti ve yeterli destekleme ödemeleri gibi önlemlerle azaltılması, ürünlerin uygun koşullarda muhafazası için çiftçilerin ortaklaşa kullanabilecekleri depoların yapılması istenmektedir. Pazarlama ile ilgili olarak ürün fiyatlarındaki dalgalanmaların devlet tarafından taban fiyat uygulaması ve ürün alımı yapılması, ürün fiyatlarının erken zamanda açıklanması gibi önlemlerle giderilmesi, periyodisiteden kaynaklanan yüksek ürün fiyat farkının azaltılması, yurt içi ve dışı satışların teşvik edilmesi, vadeli satışlarda tahsilât probleminin banka teminatı alınması gibi tedbirler getirilmesi, yüksek olan yağhane/fabrika yağ sıkım ücretlerinin makul seviyelere düşürülmesi, zeytinyağında asitlik oranının belirlenmesinde alıcı ölçümlerinin esas alınmasının önüne geçilmesi, devletin ölçüm aletlerinde belli bir standardı zorunlu tutmasının sağlanması beklenmektedir. Üreticiler örgütlenme konusunda üreticinin tüccara mecbur bırakılmamasının sağlanması için zeytincilik üretim ve pazarlamasına yönelik birlik ve kooperatif kurulmasını, bu örgütlerin kuruluşunda devletin öncülük etmesini, TARiş ve Ziraat Odalarının aktif hale getirecek tedbirlerin alınmasını, ürün alımının çoğunlukla üretici örgütleri aracılığıyla yapılmasını talep etmektedirler. Ham zeytin ve sofralık zeytine zeytinyağı primi benzeri destekleme verilmesi, desteklemelerin çiftçinin ihtiyacı olduğu dönemde verilmesi ve artırılması, alet-makine desteklerinin iyileştirilmesi, özellikle ilaçlama ve hasat makinelerinin desteklenmesi, zeytinyağı prim desteğinde yaşanan suistimallerin ortadan 
kaldırılması, tarım sigortalarının desteklemelerden kesilmesi, müşterek hisseli arazilere sahip üreticilerin kredi ve destekleme imkânlarından faydalandırılması desteklemeler ile ilgili üretici beklentileridir. Taban arazilerden ziyade eğimli arazilere zeytinliklerin kurulmasını sağlayacak teşvik tedbirlerinin alınması, zeytinliklerdeki mevcut yolların bakımının düzenli olarak yapılması, yolu olmayan eğimli araziler için herkesin ortak kullanabileceği yollar yapılması, eğimli arazilere teraslama yapılması, kadastro işlemlerinin tamamlanması, çiftçilere hazine arazilerinden zeytinlik kurulması amacıyla arazi tahsis edilmesi üreticilerinin arazi konusundaki ihtiyaçlar olarak belirlenmiştir. Üreticiler özellikle budama, zeytin hastalık ve zararlıları, hasat yöntemleri konusunda eğitimler verilmesini, eğitim çalışmalarının düzenli ve önceden haberli olarak yapılmasını ve eğitim yapılırken uygulamaya ağırlık verilmesini istemektedirler. Ayrıca, üreticilerin maden ocakları ve elektrik santrallerinin çevreye ve zeytinliklere olası etkilerinin araştırılması ve gerekli tedbirlerin alınması, iklim değişikliğinin ürün verim ve kalitesine etkilerinin araştırılması, yaşanması muhtemel orman yangınları için daha ciddi önlemlerin alınması, zeytin ve ürünlerinin muhafazasında kullanılan kaplara standardizasyon getirilmesi ve uygun kapların temini için teşvik sağlanması gibi beklentileri olduğu tespit edilmiştir. Benzer çalışmada zeytinciliğin sorunlarına üreticiler tarafından önerilen en önemli çözüm yollarının girdilere verilen desteklerin artırılması, eğitim faaliyetlerinin yapılması ve uçakla ve zamanında ilaçlama yapılması ile tüketimi artıracak çalışmaların yapılması ve tüketicilerin ürünler konusunda bilinçlendirilmesi olduğu bulunmuştur (Başaran, 2011).

\section{Sonuç ve Öneriler}

Ege Bölgesinde önemli zeytin üreticisi illeri kapsayan bu araştırmada, işletmelerin yaklaşık 4 kişilik ve çoğunlukla 15-49 yaş aralığında nüfusa sahip, erkek nüfusun üstünlüğü bulunan, \%95.88 oranında okur-yazarlık oranı ve 6.13 yıl öğrenim süresi gösteren bir yapıda olduğu bulunmuştur. Işletme yöneticilerinin orta yaş üzerinde ve öğrenim sürelerinin işletmelerin nüfus yapısına göre daha az olduğu görülmektedir. Kullanılabilir aile işgücünün yaklaşık yarısı atıl durumda olup, kullanılan işgücünün yaklaşık dörtte üçü aile işgücünden meydana gelmektedir. Ayrıca, işletmelerde yabancı işgücü içerisinde daimi işgücü kullanımının söz konusu olmadığı bulunurken geçici işgücü kullanımının işletme büyüklükleri itibariyle artış gösterdiği tespit edilmiştir.

Zeytin işletmelerinde toplam işletme arazisinin büyük çoğunluğunun mülk araziden oluştuğu belirlenirken arazi büyüklüğü arttıkça zeytin arazisi varlığının arttığı ve genel ortalamada toplam işletme arazisinin yaklaşık üçte ikisini oluşturduğu tespit edilmiştir. İşletmelerde çoğunlukla kuru tarım koşullarında zeytin üretiminin gerçekleştirilmekte olup, tarla arazisi varlığı diğer önemli arazi nev'i durumundadır.

İşletmelerin sermaye yapısı incelendiğinde aktif sermaye içerisinde arazi sermayesinin çok yüksek oranda pay aldığı belirlenirken arazi sermayesi içerisinde toprak sermayesi en önemli sermaye unsuru olduğu anlaşılmaktadır. Pasif sermaye içerisinde ise yabancı sermayenin payı arazi büyüklükleri itibariyle artmasına karşın pasif sermayeden aldığı pay oldukça düşüktür. Başka bir anlatımla, pasif sermaye içerisinde öz sermayenin payı oldukça yüksek durumdadır.

İşletmelerde ham zeytine ilişkin toplam üretim masraflarının yarısına yakınını değişken masrafların oluşturduğu belirlenmiş olup, değişken masraflar içerisinde hasat ve bakım masrafları sabit masraflarda ise arazi kirasının en önemli masraf unsurları olduğu tespit edilmiştir. İşletmelerde ham zeytin verimi ve kilograma ham zeytin maliyeti arazi büyüklükleri itibariyle azalış göstermektedir. Başka bir anlatımla, işletmelerin zeytin arazisi varlığı arttıkça ham zeytin verimi ve maliyetinin azaldığı ifade edilebilir. İşlenmiş zeytin (sofralık) ve zeytinyağı maliyetlerinde de benzer şekilde arazi büyüklükleri arttıkça maliyetlerde azalma meydana geldiği belirlenirken sofralık zeytinde fire değeri, zeytinyağında ise zeytinyağına ayrılan ham zeytin değeri en önemli masraf unsurlarıdır. Zeytin işletmelerinde üretim uygulamaları içerisinde toprak hazırlığı, gübreleme, sulama ve hasat işlemlerinde maliyetlerin yüksekliği ve işgücü yetersizliğinin en önemli sorunlar olduğu bulunurken ilaçlamada ise maliyetlerin yüksekliği ve uygulamada yetersiz bilgi diğer üretim sorunlarıdır. Ayrıca, zeytin yetiştiricilerinin devletten üretim, pazarlama, örgütlenme, arazi, eğitim ve diğer konularda birçok beklentisinin bulunduğu tespit edilmiştir.

Benzer çalışmalar ile karşılaştırmalara olanak veren bu araştırmada sonuç olarak; zeytincilik sektörünün bölgesel, ulusal ve uluslararası düzeyde sorunlarına çözüm geliştirilebilmesi için öncelikle işletme düzeyinde mevcut yapı ve sorunların bilinmesi, beklentilerin önemsenmesinin katkı sağlayacağı göz önünde bulundurulmalıdır.

a: Araştırma GOP Üniversitesi Fen Bilimleri Enstitüsü Tarım Ekonomisi ABD'de hazırlanan "Ege Bölgesinde Zeytin Yetiştiriciliği Yapan Tarım İşletmelerinin Sosyo-Ekonomik Analizi" başlıklı Doktora Tezinin bir bölümüdür. 


\section{Kaynaklar}

Açıl, A.F. 1976. Tarımsal Ürün Maliyetlerinin Hesaplanması ve Memleketimizde Tarımsal Ürün Maliyetlerinde Gelişmeler. Ankara Üniversitesi Ziraat Fakültesi Yayınları: 665, II. Baskı, Ankara.

Anaç, H. 2005. Balıkesir İli Edremit Illçesinde Zeytin Üreten İşletmelerin Ekonomik Analizi. Ankara Üniversitesi Fen Bilimleri Enstitüsü Tarım Ekonomisi Anabilim Dalı (Yüksek Lisans Tezi), Ankara.

Anonim, 2018. TÜik (www.tüik.gov.tr), (Erişim tarihi: 01.10.2018).

Anonymous, 2018. FAO (http://faostat.fao.org/), (Erişim tarihi: 01.10.2018).

Apaydın, Y.M., Sağıroğlu, D., Tosun, D., Demirbaş, N. 2014. Türkiye'de zeytinyağı sanayiinin gelişimi açısından zeytin üreticilerinin sorunları: İzmir ili örneği. Anadolu Tarım Bilimleri Dergisi, 29(3): 199-210, ISSN:13088769.

Aras, A. 1988. Tarım Muhasebesi. Ege Üniversitesi Ziraat Fakültesi Yayınları, No:486, İzmir.

Artukoglu, M.M., Olgun, F.A., Adanacioglu, H. 2010. The efficiency analysis of organic and conventional olive farms: Case of Turkey. Agricultural Economics-Czech, 56(2): 89-96.

Artukoglu, M.M., Olgun, F.A., Adanacıoglu, H. 2012. An economic analysis of organic and conventional olive production: Case of Turkey. Ege Üniversitesi Ziraat Fakültesi Dergisi, 49(3): 243-247, ISSN: 1018-8851.

Başaran, B. 2011. Zeytin ve Zeytinyağı Üreten Küçük ve Orta Ölçekli İşletmelerin Sorunları ve Bu Sorunların Çözümüne Yönelik Alternatif Öneriler. Namık Kemal Üniversitesi Fen Bilimleri Enstitüsü Tarım Ekonomisi Ana Bilim Dalı (Doktora Tezi), Tekirdağ.

Cukur, F., Saner, G., Cukur, T., Dayan, V. and Adanacioglu, H. 2013. Efficiency analysis of olive farms: The case study of Mugla province, Turkey. Journal of Food, Agriculture \& Environment, 11(2): 317-321.

Çiçek, A., Erkan, O. 1996. Tarım Ekonomisinde Araştırma ve Örnekleme Yöntemleri. GOÜ Zir. Fak. Yayınları No:12, Ders Notları Serisi No:6, Tokat.

Demirci, R. 1978. Kırşehir Merkez İlçesi Hububat İşletmelerinde Optimal İşletme Organizasyonları ve Yeter Gelirli İşletme Büyüklüklerinin Saptanması Üzerine Bir Araştırma (Doçentlik Tezi), Ankara.

Erkuş, A., Bülbül, M., Kıral, T., Açıl, A.F., Demirci, R. 1995. Tarım Ekonomisi (Ders Kitabı). Ankara Üniversitesi Ziraat Fakültesi Eğitim,
Araştırma ve Geliştirme Vakfı Yayınları No:5, Ankara.

Erkuş, A., Demirci, R. 1996. Tarımsal İşletmecilik ve Planlama. Ankara Üniversitesi Yayınları No: 1435, Ziraat Fakültesi Ders Kitabı No: 417, $158 \mathrm{~s}$, Ankara.

Esengün, K. 1990. Tokat Illinde Meyve Yetiştiriciliği Yapan İşletmelerin Ekonomik Durumu ve İşletme Sonuçlarını Etkileyen Faktörlerin Değerlendirilmesi Üzerine Bir Araştırma. Ege Üniversitesi Fen Bilimleri Enstitüsü Tarım Ekonomisi Ana Bilim Dalı (Doktora Tezi), İzmir.

Gençler, F.F. 2009. AB ve Türkiye'de Sürdürülebilir Tarım Uygulamalarının İncelenmesi ve Türkiye'de Sürdürülebilir Tarıma Yönelik Politikaların Geliştirilmesi Üzerine Bir Araştırma: Zeytin Örneği. Ege Üniversitesi Fen Bilimleri Enstitüsü Tarım Ekonomisi Anabilim Dalı (Doktora Tezi), Bornova, İzmir.

Güneş, T., Kıral, T., Arıkan, R., Bülbül, M., Çetin, B., Tatlıdil, F., Albayrak, N., Meşhur, M., Çelen, H. 1988. Başlıca Tarım Ürünleri Maliyetleri Araştırma Projesi. TMO Matbaası, Ankara.

Ilgar, R. 2016. Çanakkale ilinde zeytin yetiştiriciliği ve yaşanan sorunlar. İstanbul Üniversitesi Edebiyat Fakültesi Coğrafya Dergisi, Sayı: 32, ISNN 1305-2128.

İnan, İ.H. 2001, Tarım Ekonomisi ve İşletmeciliği. Avcı Ofset, Genişletilmiş ve Yenilenmiş Beşinci Baskı, Yayın Kodu: ISBN 975-93281-00 , İstanbul.

Karacan, A.R. 1991. Tarım İşletmelerinin Finansmanı ve Tarımsal Kredi. Ege Üniversitesi Ziraat Fakültesi Yayınları No:498, İzmir.

Karagölge, C. 1995. Tarım Ekonomisi Temel İlkeleri. Atatürk Üniversitesi Yayınları No: 801, Ziraat Fakültesi Yayınları No: 324, Ders Kitapları Serisi No: 73, Erzurum.

Karslı, I.E. 2006. Trakya ve Kuzey Ege'de Organik ve Konvansiyonel Yağlık Zeytin Üretim Ekonomisi ve Pazarlaması. Trakya Üniversitesi Fen Bilimleri Enstitüsü Tarım Ekonomisi Ana Bilim Dalı (Yüksek Lisans Tezi), Tekirdağ.

Lambarraa, F., Serra, T., Gil, J.M. 2007. Technical efficiency analysis and decomposition of productivity growth of Spanish olive farms. Spanish Journal of Agricultural Research, 5(3): 259-270, ISSN: 1695-971-X.

Olhan, E. 1997. Türkiye'de Bitkisel Üretimde Girdi Kullanımının Yarattığı Çevre Sorunları ve Organik Tarım Uygulaması-Manisa Örneği. Ankara Üniversitesi Fen Bilimleri Enstitüsü Tarım Ekonomisi Anabilim Dalı (Doktora Tezi), Ankara. 
Özalp, A., Kahraman, S., Yılmaz, İ., 2016. Manisa ili Soma ilçesinde yağlık zeytin üretiminin ekonomik analizi. XII. Ulusal Tarım Ekonomisi Kongresi, Süleyman Demirel Üniversitesi Ziraat Fakültesi Tarım Ekonomisi Bölümü, Isparta.

Özçelik, A., Turan, A., Tanrıvermiş, H. 1998. Türkiye'de Tarımın Pazara Entegrasyonunda Sözleşmeli Tarım ve Bu Modelin Sürdürülebilir Kaynak Kullanımı ile Üretici Geliri Üzerine Etkileri. Tarımsal Ekonomi Araştırma Enstitüsü Yayınları Yayın No: 14, Ankara.

Özgürsoy, S. 2006. Hatay Illinde Zeytin ve Zeytinyağı Sektörünün Ekonomik Analizi. Çukurova Üniversitesi Fen Bilimleri Enstitüsü Tarım Ekonomisi Ana Bilim Dalı (Doktora Tezi), Adana.

Seçer, A. 2012. Doğu Akdeniz Bölgesi'nde Zeytin ve Zeytinyağı Üretimi, Pazarlaması ve Bölgede Zeytinciliği Geliştirme Olanakları. Çukurova Üniversitesi Fen Bilimleri Enstitüsü Tarım Ekonomisi Anabilim Dalı (Doktora Tezi), Adana.

Tiryakioğlu, M. 2011. Sofralık Zeytin Üretimi ve Dış Satım Olanakları Üzerine Bir Araştırma: Akhisar İlçesi Örneği. Ege Üniversitesi Fen Bilimleri Enstitüsü Tarım Ekonomisi Ana Bilim Dalı (Yüksek Lisans Tezi), Bornova, İzmir.

Tunalıoğlu, R., Gökçe, O. 2002. Ege Bölgesinde optimal zeytin yayılış alanlarının tespitine yönelik bir araştırma. Tarım ve Köyişleri Bakanlığı Tarımsal Ekonomi Araştırma Enstitüsü, Ankara.

Yapıcı, Ç. 2006. Balıkesir İli Burhaniye İlçesinde Yağlık Zeytin Üreten İşletmelerin Ekonomik Analizi. Çanakkale Onsekiz Mart Üniversitesi Fen Bilimleri Enstitüsü Tarım Ekonomisi Ana Bilim Dalı (Yüksek Lisans Tezi), Çanakkale. 